\title{
FAKTOR-FAKTOR YANG MEMPENGARUHI KINERJA UMKM DI WILAYAH PURWOKERTO KABUPATEN BANYUMAS
}

\author{
Hamdan Naufal Azhari \\ Universitas Jenderal Soedirman \\ naufal.azhari@gmail.com \\ Negina Kencono Putri \\ Universitas Jenderal Soedirman \\ negina.putri@unsoed.ac.id \\ Irianing Suparlinah \\ Universitas Jenderal Soedirman \\ irianing@yahoo.com
}

\begin{abstract}
The aims of this research was to determine the effect of funding, HR competencies, entrepreneurial orientation and financial literacy on MSMEs performance. The number of respondents obtained in this research was 100 MSMEs entrepreneurs which are divided from four districts in Purwokerto. The sampling method used was disproportionate stratified sampling. Based on the results of research and data analysis using multiple linear regression models show that: (1) funding has a significant effect on MSME performance, (2) HR competence has a significant effect on MSME performance, (3) entrepreneurial orientation has a significant effect on MSME performance, (4) financial literacy has no effect on the performance of MSMEs. Implication of the result is MSMEs entrepreneurs in Purwokerto Region should pay attention to factors related to MSMEs performance which are: adding funding for their businesses, understand about the products, has the ability and expertise in its production activities. MSMEs entrepreneurs must also pay attention to every opportunity that exists and dare to take risks to try their creative ideas.
\end{abstract}

Keywords: Funding, HR Competence, Entrepreneurial Orientation, Financial Literacy and MSMEs Perfomance

\begin{abstract}
ABSTRAK
Tujuan dari penelitian ini adalah untuk mengetahui pengaruh pendanaan, kompetensi SDM, orientasi kewirausahaan dan literasi keuangan terhadap kinerja UMKM. Jumlah responden yang diperoleh dalam penelitian ini adalah 100 pelaku UMKM yang terbagi dari empat kecamatan di Wilayah Purwokerto. Metode pengambilan sampel yang digunakan adalah sampel berstrata tidak proporsional. Berdasarkan hasil penelitian dan analisis data menggunakan model regresi linier berganda menunjukkan bahwa: (1) pendanaan berpengaruh signifikan terhadap kinerja UMKM, (2) kompetensi SDM berpengaruh signifikan terhadap kinerja UMKM, (3) orientasi kewirausahaan berpengaruh signifikan terhadap kinerja UMKM, (4) literasi keuangan tidak berpengaruh terhadap kinerja UMKM. Implikasi dari hasilnya adalah para pelaku UMKM di Wilayah Purwokerto harus memperhatikan
\end{abstract}


faktor-faktor yang berkaitan dengan kinerja UMKM, diantaranya: menambahkan pendanaan untuk bisnis mereka, memahami tentang produk yang dihasilkan, memiliki kemampuan dan keahlian dalam kegiatan produksinya. Pelaku UMKM juga harus memperhatikan setiap peluang yang ada dan berani mengambil risiko untuk mencoba ide-ide kreatif mereka.

Kata kunci: Pendanaan, Kompetensi SDM, Orientasi Kewirausahaan, Literasi Keuangan dan Kinerja UMKM

\section{PENDAHULUAN}

Pertumbuhan UMKM di Kabupaten Banyumas dari tahun ke tahun terus mengalami peningkatan. Sektor UMKM di Kabupaten Banyumas juga berkontribusi dalam penyerapan tenaga kerja, dimana per Januari 2015 menurut data yang dihimpun dari Dinnakerkopukm Kabupaten Banyumas jumlah tenaga kerja yang diserap UMKM binaan mencapai 101.177 orang. Hal ini yang kemudian memacu pelaku UMKM agar menciptakan usaha yang berbeda sehingga memiliki suatu ciri khas, tentunya dengan kinerja yang baik. Kinerja merupakan ukuran keberhasilan sebuah entitas usaha dalam mencapai tujuannya. Kinerja merupakan hasil pekerjaan yang mempunyai hubungan kuat dengan tujuan strategis organisasi, kepuasan konsumen dan memberikan kontribusi pada ekonomi.

Pengukuran kinerja memiliki peranan penting dalam segala aspek operasional untuk mencapai visi dan misi usaha tersebut. Pelaku UMKM harus mengetahui terlebih dahulu ukuran kinerja yang harus mereka gunakan. Salah satu metode yang dapat dipakai untuk mengukur kinerja suatu perusahaan ialah menggunakan Balanced Scorecard (BSC). BSC merupakan sistem manajemen, pengukuran, dan pengendalian yang secara cepat, tepat, dan komprehensif yang dapat ememberikan pemahaman kepada manajer tentang kinerja usaha (Kaplan dan Norton, 2000). Pengukuran kinerja tersebut memandang unit bisnis dari empat perspektif, yaitu perspektif keuangan, pelanggan, proses bisnis dalam perusahaan, serta proses pembelajaran dan pertumbuhan.

Pada umumnya pelaku UMKM memiliki keterbatasan pada pengetahuan luas, sehingga kurang berorientasi jangka panjang. Upaya meningkatkan kinerjanya pun cenderung konvensional karena kurangnya pengetahuan dalam sisi manajemen. Beberapa masalah lain yang sering dihadapi para pelaku UMKM diantaranya keterbatasan pendanaan, kompetensi sumber daya manusia, orientasinya terhadap kewirausahaan serta literasi pada keuangan. Masalah tersebut akan berdampak pada kinerja UMKM apabila tidak ditangani dengan baik. Penelitian ini bertujuan untuk mencari tahu pengaruh pendanaan, kompetensi SDM, orientasi kewirausahaan dan literasi keuangan terhadap kinerja UMKM di Wilayah Purwokerto.

\section{TELAAH LITERATUR DAN PENGEMBANGAN HIPOTESIS}

\section{Kinerja UMKM}

Kinerja UMKM merupakan hasil kerja UMKM yang dicapai secara keseluruhan dengan memperhatikan hasil kerja, target, dan sasaran yang telah ditentukan (Tambunan, 2009). Penilaian kinerja UMKM dalam penelitian ini ialah dengan mengukur empat perspektif yang terdapat dalam metode balancse scorecard: (a) keuangan, (b) pelanggan, (c) proses bisnis intenal, (d) Perspektif pembelajaran dan pertumbuhan. 


\section{Pendanaan}

Pendanaan adalah sumber modal yang digunakan oleh pengusaha sebagai penggerak kegiatan operasional usaha (Brigham \& Houston, 2011).

\section{Kompetensi SDM}

Kompetensi menurut Mitrani dalam Ardiana et al. (2010) merupakan karakteristik yang mendasari seseorang dan memiliki keterkaitan dengan efektivitas kinerja individu dalam pekerjaannya. Kompetensi individu yang melekat dalam dirinya dan dapat digunakan untuk memprediksi tingkat kinerjanya.

\section{Orientasi Kewirausahaan}

Orientasi kewirausahaan merupakan perilaku wirausahawan yang memiliki kemampuan dalam melihat peluang usaha baru dengan berbagai macam resikonya untuk diidentikasi serta dimanfaatkan (Suparlinah, 2018).

\section{Literasi Keuangan}

Literasi keuangan merupakan kemampuan yang dimiliki individu untuk mengerti, mengetahui dan memahami tentang tata cara pengelolaan keuangan dengan baik.Ulfatun dalam Ningsih (2016) mengartikan literasi keuangan sebagai pengetahuan keuangan dengan tujuan untuk mencapai kesejahteraan.

\section{Pengembangan Hipotesis}

Brigham \& Houston (2011) menyatakan bahwa struktur modal yang tepat dapat memengaruhi kinerja sebuah perusahaan secara finansial. Pelaku UMKM pada umumnya menjalankan usahanya hanya menggunakan sumber pendanaan pribadi. Opsi lain yang mereka pilih untuk mengembangkan usahanya adalah dengan menambah sumber pendanaan melalui hutang. Namun penambahan sumber pendanaan ini harus diperhatikan pula manfaat dan biayanya terhadap kondisi keuangan UMKM tersebut. Berdasarkan teori dan argumen pendukung tersebut, maka hipotesis pertama penelitian ini adalah:

\section{$\mathrm{H}_{1}$ : Pendanaan berpengaruh terhadap kinerja UMKM di Wilayah Purwokerto.}

Kompetensi SDM yang dimiliki pelaku UMKM juga merupakan salah satu faktor yang mendorong individu untuk melakukan seuatu agar dapat mengembangkan usahanya. Pelaku dengan kompetensi SDM yang mumpuni dapat melakukan pekerjaannya dengan maksimal. Hal tersebut dapat meningkatkan kinerja UMKM karena pelaku UMKM memiliki kemampuan dan pengetahuan yang jelas terhadap usahanya. Berdasarkan pemaparan tersebut, hipotesis kedua penelitian ini adalah:

\section{$\mathrm{H}_{2}$ : Kompetensi SDM berpengaruh terhadap kinerja UMKM di Wilayah Purwokerto.}

Selain itu, orientasi kewirausahaan merupakan strategi benefit yang dimiliki pelaku UMKM untuk dapat berkompetisi secara efektif di dalam persaingan yang seimbang. Maka dari itu diperlukan inovasi untuk menciptakan hal-hal yang baru yang sesuai akan kebutuhan 
pasar. UMKM diharapkan dapat terus bertahan dalam persaingan dan menjalankan operasionalnya. Berdasarkan pemaparan tersebut, hipotesis keempat penelitian ini adalah:

\section{$\mathrm{H}_{3}$ : Orientasi kewirausahaan berpengaruh terhadap Kinerja UMKM di Wilayah Purwokerto}

Literasi keuangan merupakan salah satu kemampuan yang harus dimiliki oleh tiap pelaku UMKM saat ini. Kemampuan untuk mengelola keuangan usaha merupakan salah satu tujuan yang harus dicapai agar pelaku UMKM dapat menentukan keputusan finansial yang tepat. Kinerja perusahaan dapat meningkat apabila setiap keputusan keuangan yang diambil pelaku UMKM sesuai dengan kondisi usahanya. Berdasarkan pemaparan dari argumen pendukung tersebut, maka dapat disimpulkan hipotesis keempat sebagai berikut :

\section{$\mathrm{H}_{4}$ : Literasi keuangan berpengaruh terhadap Kinerja UMKM di Wilayah Purwokerto.}

\section{METODE PENELITIAN}

\section{Desain Penelitian}

Penelitian ini dilakukan dengan menggunakan pendekatan kuantitatif. Objek penelitian ini mencakup Usaha Mikro, Kecil, dan Menengah yang ada di wilayah Purwokerto Utara, Purwokerto Timur, Purwokerto Selatan dan Purwokerto Barat. Subjek penelitian ini adalah para pelaku UMKM, yang bisa merupakan seorang pemilik atau manajer UMKM di Wilayah Purwokerto.

\section{Populasi dan Sampel}

Populasi penelitian ini adalah seluruh UMKM di Wilayah Purwokerto. Pengambilan sampel dilakukan dengan menggunakan teknik disproportionate stratified sampling. Jumlah sampel yang ditargetkan 111 responden.

\section{Teknik Pengumpulan Data dan Teknik Analisis}

Sumber data yang diperoleh adalah dengan melihat hasil penyebaran kuesioner. Kuesioner penelitian ini ialah modifikasi dari kuesioner dalam penelitian Munizu (2010); Ardiana et al. (2010); Sari (2016); Ningsih (2018). Pengukuran variabel-variabel bebas dan terikat dalam penelitian ini menggunakan Skala Likert dengan skor 1-5. Teknik analisis penelitian ini menggunakan model regresi linear berganda dengan bantuan program IBM SPSS Statistics 25. Beberapa uji harus dilakukan sebelum melakukan pengujian hipotesis, diantaranya uji validitas, reliabilitas dan uji asumsi klasik (normalitas, multikolinearitas dan heteroskedastisitas).

\section{HASIL PENELITIAN DAN PEMBAHASAN}

\section{Gambaran Umum Penelitian}

Berdasarkan data yang berhasil dikumpulkan selama penelitian, kuesioner yang diperoleh mengunakan cara manual sebanyak 22 buah dan yang diperoleh menggunakan kuesioner online sebanyak 78 buah. Terdapat 11 kuesioner yang tidak mendapatkan respon dari pemilik/manajer UMKM hingga jangka waktu yang telah ditentukan. Peneliti akhirnya 
memutuskan untuk tidak mengikutsertakan 11 kuesioner tersebut untuk menghindari non response bias. Tabel 1. menjelaskan sebaran responden berdasarkan sektor industri dan skala usahanya:

Tabel 1

Sebaran Responden Berdasarkan Sektor Industri dan Skala Usaha

\begin{tabular}{lllccc}
\hline \multirow{2}{*}{ No. Sektor } & \multicolumn{1}{c}{ Skala Usaha } & \multirow{2}{*}{ Jumlah } \\
\cline { 3 - 5 } & & Mikro & Kecil & Menengah & \\
\hline 1. & Pertanian, Peternakan, Kehutanan Dan & - & 1 & - & 1 \\
2. & Perikanan & - & - & - & - \\
3. & Industri Pengolahan & 3 & - & - & 3 \\
4. & Listrik, Gas Dan Air Bersih & 1 & - & - & 1 \\
5. & Bangunan & 2 & 1 & - & 3 \\
6. & Perdagangan, Hotel Dan Restoran & 41 & 9 & - & 50 \\
7. & Pengangkutan Dan Komunikasi & 4 & 1 & 1 & 6 \\
8. & Keuangan, Persewaan Dan Jasa Perusahaan & 4 & - & - & 4 \\
9. & Jasa - Jasa Swasta & 30 & 2 & - & 32 \\
\hline & Total & 85 & 14 & 1 & 100 \\
\hline
\end{tabular}

\section{Analisis Data}

\section{Uji Validitas dan Reliabilitas}

Uji validitas dan reliabilitas instrumen penelitian ini menggunakan program IBM SPSS Statistics 25 dengan melibatkan 30 responden. Semua item pertanyaan memiliki $r_{\text {hitung }}>r_{\text {tabel }}$ yaitu 0,349 yang membuktikan bahwa semua pertanyaan dinyatakan valid. Kemudian untuk menguji reliabilitas instrumen dicari nilai Cronbanch's Alpha tiap variabel. Hasilnya pendanaan memiliki nilai 0,743, kompetensi SDM 0,638, orientasi kewirausahaan 0,683, literasi keuangan 0,802 dan literasi keuangan 0,633 . Semua nilai tiap variabel memiliki nilai lebih besar dari 0,6 sehingga dapat ditarik kesimpulan bahwa instrumen penelitian dinyatakan reliabel.

\section{Uji Asumsi Klasik}

Uji normalitas dilakukan untuk mencari tahu apakah variabel pengganggu atau residual berdistribusi normal atau tidak. Teknik yang digunakan ialah dengan Kolmogorov Smirnov. Diketahui nilai Sig 0,200>0,05 yang berarti nilai residual pada penelitian ini berdistribusi normal. Selanjutnya uji multikolinearitas dilakukan untuk menngetahui apakah terdapat korelasi antara variabel independen. Hasil dari pengujian multikolinearitas dijelaskan pada tabel 2 sebagai berikut:

Tabel 2

Hasil Uji Multikolinearitas

\begin{tabular}{ccc}
\hline \multirow{2}{*}{ Variable } & \multicolumn{2}{c}{ Collinearity Statistics } \\
\cline { 2 - 3 } & Tolerance & VIF \\
\hline Pendanaan & 0,856 & 1,168 \\
Kompetensi SDM & 0,855 & 1,170
\end{tabular}




\begin{tabular}{ccc} 
Orientasi Kewirausahaan & 0,808 & 1,238 \\
Literasi Keuangan & 0,947 & 1,056 \\
\hline
\end{tabular}

Diketahui bahwa seluruh variabel independen memiliki nilai Tolerance $\geq 0,10$ dan VIF $\leq 10$. Nilai tersebut menunjukkan bahwa seluruh variabel independen dalam penelitian ini tidak terjadi multikolinearitas. Uji heteroskedastisitas dilakukan untuk menguji apakah dalam model regresi dalam penelitian ini terjadi ketidaksamaan variance dari residual satu pengamatan ke pengamatan lainnya. Hasil pengujian heteroskedastisitas dapat dilihat dalam tabel 3 sebagai berikut:

Tabel 3

Hasil Uji Heteroskedastisitas

\begin{tabular}{cc}
\hline Variable & Sig. \\
\hline Pendanaan & 0,086 \\
Kompetensi SDM & 0,888 \\
Orientasi Kewirausahaan & 0,171 \\
Literasi Keuangan & 0,139 \\
\hline
\end{tabular}

Berdasarkan tabel 3 diketahui nilai Sig tiap variabel >0,05, maka seluruh variabel dapat dikatakan bebas heteroskedastisitas. Hasil ini menyimpulkan bahwa model regresi tidak memiliki masalah heteroskedastisitas.

Analisis Regresi Linear Berganda

Tabel 4

Hasil Uji Regresi Linear Berganda

\begin{tabular}{lccc}
\hline \multirow{2}{*}{ Model } & \multicolumn{2}{c}{$\begin{array}{c}\text { Unstandardized } \\
\text { Coefficients }\end{array}$} & $\begin{array}{c}\text { Standardized } \\
\text { Coefficients }\end{array}$ \\
\cline { 2 - 4 } & B & Std.Error & Beta \\
\hline (Constant) & 0,447 & 2,303 & \\
Pendanaan & 0,332 & 0,062 & 0,421 \\
Kompetensi SDM & 0,268 & 0,089 & 0,237 \\
Orientasi Kewirausahaan & 0,442 & 0,123 & 0,292 \\
Literasi Keuangan & 0,031 & 0,075 & 0,031 \\
\hline
\end{tabular}

Tabel 4 memperlihatkan berbagai kolom yang diisi angka-angka untuk mencari persamaan regresi linear bergandanya. Angka-angka tersebut apabila dimasukan kedalam persamaan regresi linear berganda menjadi:

$$
Y=0,447+0,332 X_{1}+0,268 X_{2}+0,442 X_{3}+0,031 X_{4}
$$

Persamaan regresi tersebut dapat diinterpretasikan nilai konstanta sebesar 0,447 yang artinya jika nilai variabel independen sama dengan 0 maka nilai $\mathrm{Y}$ adalah 0,447 . Kinerja UMKM memiliki nilai sebesar 0,447 apabila tidak ada pendanaan, kompetensi sdm, orientasi kewirausahaan dan literasi keuangan. Nilai koefisien regresi pendanaan sebesar 0,332 
memiliki arti setiap peningkatan satu unit variabel pendanaan dengan asumsi nilai variabel independen lain konstan akan menyebabkan peningkatan pada kinerja UMKM sebesar 0,332. Hal serupa juga berlaku bagi nilai koefisien regresi variabel lainnya.

\section{Uji Goodness of Fit}

Hal pertama yang dilakukan ialah mencari nilai $F_{\text {tabel }}$ pada tabel statistik untuk signifikansi 0,05 dengan df : $\alpha,(\mathrm{k}-1),(\mathrm{n}-\mathrm{k})$. Hasil diperoleh untuk nilai $\mathrm{F}_{\text {tabel }}$ pada signifikansi 0,05 dengan df : $\alpha,(5-1)$, (100-5) sebesar 2,467. Selanjutnya mencari $F_{\text {hitung }}$ dengan hasil sebagai berikut:

\section{Tabel 5}

Hasil Uji F

\begin{tabular}{|c|c|c|c|c|c|c|}
\hline \multicolumn{2}{|c|}{ Model } & Sum of Squares & Df & Mean Square & $\mathbf{F}$ & Sig \\
\hline \multirow{3}{*}{1} & Regression & 134,033 & 4 & 33,508 & 23,212 & $0,000^{\mathrm{b}}$ \\
\hline & Residual & 137,138 & 95 & 1,444 & & \\
\hline & Total & 271,171 & 99 & & & \\
\hline
\end{tabular}

Berdasarkan hasil output uji $\mathrm{F}$ pada tabel 5 dapat dilihat bahwa $\mathrm{F}_{\text {hitung }}$ sebesar 23,212 > nilai $F_{\text {tabel }}$ sebesar 2,467 dengan tingkat signifikansi $0,000<0,05$. Kesimpulan yang dapat diambil dari hasil tersebut adalah pendanaan, kompetensi SDM, orientasi kewirausahaan dan literasi keuangan berpengaruh signifikan secara simultan terhadap kinerja UMKM.

\section{Uji Koefisien Determinasi $\left(R^{2}\right)$}

\begin{tabular}{lc}
\multicolumn{2}{c}{ Tabel 6} \\
Hasil Uji Koefisien & Determinasi \\
\cline { 2 - 2 } Keterangan & Nilai \\
\hline R & 0,703 \\
R Square & 0,494 \\
Adjusted R & 0,473 \\
Square & \\
Std. Error of & 1,20148 \\
the Estimate & \\
\hline
\end{tabular}

Berdasarkan tabel 6 diperoleh nilai $\mathrm{R}^{2}$ sebesar 0,473 atau 47,3\%. Nilai tersebut menunjukkan bahwa persentase sumbangan variabel independen dalam penelitian ini terhadap kinerja UMKM sebesar 47,3\%, sedangkan sisanya dijelaskan oleh variabel lain yang tidak ada dalam model regresi penelitian ini.

\section{Pengujian Hipotesis (Uji t)}

Pengujian dilakukan dengan membandingkan $t_{\text {hitung }}$ masing-masing variabel independent dengan $t_{\text {tabel }}$. Pertama yang dilakukan adalah mencari nilai $t_{\text {tabel }}$ dengan melihat tabel t pada signifikansi $\alpha / 2=5 \% / 2=2,5 \%$ dan d.f $(n-k)=(100-5)=95$, maka ditemukan $t_{\text {tabel }}$ sebesar 1,985. Langkah selanjutnya mencari $t_{\text {hitung }}$ dan berikut merupakan hasil perhitungannya: 
Tabel 7

Hasil Uji t

\begin{tabular}{|c|c|c|c|c|c|c|}
\hline \multirow{2}{*}{\multicolumn{2}{|c|}{ Model }} & \multicolumn{2}{|c|}{$\begin{array}{l}\text { Unstandardized } \\
\text { Coefficients }\end{array}$} & \multirow{2}{*}{$\begin{array}{c}\begin{array}{c}\text { Standarized } \\
\text { Coefficients }\end{array} \\
\text { Beta } \\
\end{array}$} & \multirow{2}{*}{$\mathbf{t}$} & \multirow{2}{*}{ Sig. } \\
\hline & & B & Std. Error & & & \\
\hline \multirow[t]{5}{*}{1} & (Constant) & 0,447 & 2,303 & & 0,194 & 0,847 \\
\hline & Pendanaan & 0,332 & 0,062 & 0,421 & 5,336 & 0,000 \\
\hline & Kompetensi SDM & 0,268 & 0,089 & 0,237 & 2,999 & 0,003 \\
\hline & $\begin{array}{l}\text { Orientasi } \\
\text { Kewirausahaan }\end{array}$ & 0,442 & 0,123 & 0,292 & 3,597 & 0,001 \\
\hline & Literasi Keuangan & 0,031 & 0,075 & 0,031 & 0,417 & 0,677 \\
\hline
\end{tabular}

Berdasarkan tabel 7 nilai $t_{\text {hitung }}$ pendanaan $5,336>$ dari $t_{\text {tabel }} 1,985$ dan nilai signifikansinya sebesar $0,000<$ dari 0,05 . Hal tersebut membuktikan bahwa pendanaan $\left(\mathrm{X}_{1}\right)$ berpengaruh signifikan terhadap kinerja UMKM (Y), sehingga $\mathrm{H}_{1}$ diterima. Nilai $t_{\text {hitung }}$ kompetensi SDM 2,999 > dari $t_{\text {tabel }} 1,985$ dan nilai signifikansinya sebesar $0,003<$ dari 0,05 . Hal tersebut membuktikan bahwa kompetensi SDM $\left(\mathrm{X}_{2}\right)$ berpengaruh signifikan terhadap kinerja UMKM (Y), sehingga $\mathrm{H}_{2}$ diterima. Nilai $\mathrm{t}_{\text {hitung }}$ orientasi kewirausahaan 3,597> dari $\mathrm{t}_{\text {tabel }} 1,985$ dan nilai signifikansinya sebesar $0,001<$ dari 0,05 . Hal tersebut membuktikan bahwa orientasi kewirausahaan $\left(\mathrm{X}_{3}\right)$ berpengaruh signifikan terhadap kinerja UMKM $(\mathrm{Y})$, sehingga $\mathrm{H}_{3}$ diterima. Nilai $\mathrm{t}_{\text {hitung }}$ literasi keuangan $0,417<$ dari $\mathrm{t}_{\text {tabel }} 1,985$ dan nilai signifikansinya sebesar 0,677> dari 0,05. Hal tersebut membuktikan bahwa literasi keuangan $\left(\mathrm{X}_{4}\right)$ tidak berpengaruh terhadap kinerja UMKM (Y), sehingga $\mathrm{H}_{4}$ ditolak.

\section{Pembahasan}

Hasil penelitian ini mengindikasikan pendanaan berpengaruh signifikan secara parsial terhadap kinerja UMKM di Wilayah Purwokerto. Pendanaan masih menjadi hal yang utama bagi para pelaku UMKM di Wilayah Purwokerto untuk mengembangkan usaha mereka. Hasil penelitian ini mendukung penemuan yang dikemukakan oleh Wahba (2018) yang menyimpulkan kebijakan pendanaan yang baik akan meningkatkan nilai perusahaannya jika perusahaan menggunakan sumber ekonomi yang dimiliki secara efektif dan efisien. Kompetensi SDM juga berpengaruh signifikan secara parsial terhadap kinerja UMKM di Wilayah Purwokerto. Pernyataan pada kuesioner penelitian ini juga menunjukkan bahwa kemampuan yang dimiliki pelaku UMKM tergolong baik. Hal tersebut dibuktikan dengan nilai tertinggi pada indikator kemampuan yang menjelaskan kemampuan bekerjasama dan mampu mengemban tanggung jawab. Hal tersebut sejalan dengan penelitiannya Widjaja (2018) yang menyatakan tingginya tingkat kompetensi SDM yang dimiliki pelaku UMKM.

Hasil lainnya menjelaskan bahwa orientasi kewirausahaan berpengaruh signifikan secara parsial terhadap kinerja UMKM di Wilayah Purwokerto. Orientasi kewirausahaan yang tinggi membantu para pelaku UMKM Purwokerto dapat menciptakan produk yang lebih khas dan melakukan percobaan walaupun beresiko. Temuan ini menjelaskan bahwa UMKM di Wilayah Purwokerto telah melakukan upaya penerapan orientasi kewirausahaan sebagai landasan menjalankan aktivitas bisnis. Hasil penelitian ini sejalan dengan Sari (2016) yang 
menjelaskan peningkatan kinerja UMKM tidak terlepas dari kemampuan pelaku UMKM dalam memahami konsep orientasi kewirausahaan (proaktif terhadap peluang, inovatif, kreatif dan keberanian mengambil resiko). Hasil berbeda didapat pada variabel literasi keuangan yang tidak berpengaruh secara parsial terhadap kinerja UMKM di Wilayah Purwokerto. Literasi keuangan tidak berpengaruh terhadap kinerja UMKM karena sebagian besar pelaku UMKM di Wilayah Purwokerto masih belum dapat memanfaatkan penghasilannya dengan baik. Temuan lainnya, masih banyak pengusaha yang menggabungkan keuangan pribadi dengan usaha nya. Hal ini membuat kondisi keuangan usaha mereka menjadi tidak diketahui pastinya dikarenakan tidak tahu mana uang perusahaan mana uang pribadi. Hasil penelitian ini sejalan oleh penelitian Suryanto (2018) yang menjelaskan literasi keuangan pelaku UMKM masih rendah. Beberapa faktor yang mempengaruhi tinggi rendahnya literasi seseorang ialah diantaranya pengaruh usia, tingkat pendidikan, pendapatan yang diterima, dll. Terlebih lagi $84 \%$ dari mereka tidak pernah menerima pelatihan usaha yang biasa diberikan oleh dinas atau instansi terkait.

\section{KESIMPULAN DAN SARAN}

Berdasarkan hasil analisis data dan pembahasan yang dilakukan pada penelitian ini maka dapat ditarik kesimpulan: (1) menerima hipotesis kesatu $\left(\mathrm{H}_{1}\right)$ yaitu pendanaan berpengaruh signifikan terhadap kinerja UMKM di Wilayah Purwokerto. (2) menerima hipotesis kedua $\left(\mathrm{H}_{2}\right)$ yaitu kompetensi SDM berpengaruh signifikan terhadap kinerja UMKM di Wilayah Purwokerto. (3) menerima hipotesis ketiga $\left(\mathrm{H}_{3}\right)$ yaitu orientasi kewirausahaan berpengaruh signifikan terhadap kinerja UMKM di Wilayah Purwokerto. (4) menolak hipotesis keempat $\left(\mathrm{H}_{4}\right)$ yaitu literasi keuangan tidak berpengaruh terhadap kinerja UMKM di Wilayah Purwokerto.

Penelitian ini tidak terlepas dari berbagai keterbatasan maupun kekurangan yang ada. Di sisi lain, keterbatasan dan kelemahan yang ada pada penelitian ini dapat dijadikan sumber masukan bagi penelitian mendatang. Keterbatasan penelitian ini terkait dengan proporsi responden usaha menengah yang sebagian besar tidak memberikan tanggapan pada kuesioner hingga masa waktu yang sudah ditetapkan dikarenakan masalah birokrasi perusahaan. Jika penelitian mendatang ingin mengambil responden dari sebuah perusahaan dengan birokrasi yang sudah besar disarankan selain dengan mengirim kuesioner langsung ke tempatnya, dikirim pula melalui surat elektronik atau dapat membuat perjanjian terlebih dahulu untuk melakukan interview.

\section{REFERENSI}

Ardiana, I.D.K.R., I.A. Brahmayanti, Subaedi. (2010). Kompetensi SDM UKM dan Pengaruhnya Terhadap Kinerja UKM di Surabaya. Jurnal Manajemen dan Kewirausahaan. 12. 42-55.

Brigham, Eugene F. \& Joel F. Houston. (2011). Dasar-Dasar Manajemen Keuangan Buku 2 (Edisi 11). Jakarta: Salemba Empat. 
Departemen Koperasi. (2018). Daftar UMKM Seluruh Indonesia. Jakarta: Penulis. Diakses dari http://www.depkop.go.id/.

Munizu, Musran. (2010). Pengaruh Faktor-Faktor Eksternal dan Internal Terhadap Kinerja Usaha Mikro Kecil (UMK) di Sulawesi Selatan. Jurnal Manajemen dan Kewirausahaan Universitas Hasanuddin. 12. 33-41.

Ningsih, Suci Etika. (2018). Pengaruh Literasi Keuangan Terhadap Kinerja Usaha Mikro, Kecil, dan Menengah di Kabupaten Jember (skripsi). Tersedia dari Digital Repository Universitas Jember. (No. 87431).

Kaplan, R. S., \& Norton, D. P. (2000). Balanced Scorecard : Menerapkan Strategi Menjadi Aksi. Jakarta: Erlangga.

Sari, Indra Yanti. (2016). Pengaruh Orientasi Kewirausahaan dan Inovasi Produk terhadap Kinerja UKM Kota Makassar (skripsi). Tersedia dari Repositori UIN Alauddin Makassar. (No. 5034)

Suparlinah, Irianing et al. (2018). Entrepreneurial Orientation and Business Scale Effect on the Micro and Small Enterprises (MSEs) Performance: A Case in Banyumas, Centra Java, Indonesia. Economy Transdisciplinarity Cognition. 21. 44-50.

Suryanto \& Mas Rasmini. 2018. Analisis Literasi Keuangan dan Faktor-Faktor yang Mempengaruhinya (Survey pada Pelaku Usaha Mikro, Kecil, dan Menengah di Kota Bandung). Jurnal Ilmu Politik dan Komunikasi. 8.

Tambunan, Tulus T.H. (2009). UMKM DI INDONESIA (Cetakan pertama). Bogor: Ghalia Indonesia.

Wahba. (2018). Pengaruh Kebijakan Pendanaan dan Modal Kerja terhadap Profitabilitas Usaha Mikro Kecil dan Menengah di Kecamatan Banawa. Jurnal Katalogis. 6. 195-203.

Widjaja, Yani Restiani et al. (2018). Peranan Kompetensi SDM UMKM dalam Meningkatkan Kinerja UMKM Desa Cilayung Kecamatan Jatinangor, Sumedang. Jurnal Abdimas BSI. 1. 465-476. Diakses dari https://ejournal.bsi.ac.id/ejurnal/index.php/abdimas/article/view/4012. 